\title{
Culture of rat mesenchymal stem cells on PHBV-PCL scaffolds: analysis of conditioned culture medium by FT-Raman spectroscopy
}

\author{
Cultivo de células-tronco mesenquimais de rato sobre arcabouços de PHBV-PCL: \\ análise do meio de cultura condicionado por espectroscopia de FT-Raman \\ V. A. Nascimento ${ }^{\mathrm{a}}$ (D), S. M. Malmonge ${ }^{\mathrm{b}}$ (D) A. R. Santos Jr. ${ }^{\mathrm{a}}$ (1) \\ aUniversidade Federal do ABC, Centro de Ciências Naturais e Humanas - CCNH, São Bernardo do Campo, SP, Brasil \\ bUniversidade Federal do ABC, Centro de Engenharia, Modelagem e Ciências Sociais Aplicadas, São Bernardo do Campo, SP, Brasil.
}

\begin{abstract}
Mesenchymal stem cells (MSCs) have great potential for application in cell therapy and tissue engineering procedures because of their plasticity and capacity to differentiate into different cell types. Given the widespread use of MSCs, it is necessary to better understand some properties related to osteogenic differentiation, particularly those linked to biomaterials used in tissue engineering. The aim of this study was to develop an analysis method using FT-Raman spectroscopy for the identification and quantification of biochemical components present in conditioned culture media derived from MSCs with or without induction of osteogenic differentiation. All experiments were performed between passages 3 and 5. For this analysis, MSCs were cultured on scaffolds composed of bioresorbable poly(hydroxybutyrateco-hydroxyvalerate) (PHBV) and poly ( $\varepsilon$-caprolactone) $(\mathrm{PCL})$ polymers. MSCs (GIBCO $($ ) were inoculated onto the pure polymers and 75:25 PHBV/PCL blend (dense and porous samples). The plate itself was used as control. The cells were maintained in DMEM (with low glucose) containing GlutaMAX® and $10 \% \mathrm{FBS}$ at $37^{\circ} \mathrm{C}$ with $5 \% \mathrm{CO}_{2}$ for 21 days. The conditioned culture media were collected and analyzed to probe for functional groups, as well as possible molecular variations associated with cell differentiation and metabolism. The method permitted to identify functional groups of specific molecules in the conditioned medium such as cholesterol, phosphatidylinositol, triglycerides, beta-subunit polypeptides, amide regions and hydrogen bonds of proteins, in addition to DNA expression. In the present study, FT-Raman spectroscopy exhibited limited resolution since different molecules can express similar or even the same stretching vibrations, a fact that makes analysis difficult. There were no variations in the readings between the samples studied. In conclusion, FT-Raman spectroscopy did not meet expectations under the conditions studied.
\end{abstract}

Keywords: biomaterials, tissue engineering, cell differentiation, vibrational spectroscopy.

\begin{abstract}
Resumo
As células-tronco mesenquimais (MSCs) possuem grande potencial para aplicação em procedimentos terapêuticos ligados a terapia celular e engenharia de tecidos, considerando-se a plasticidade e capacidade de formação em diferentes tipos celulares por elas. Dada a abrangência no emprego das MSCs, há necessidade de se compreender melhor algumas propriedades relacionadas à diferenciação osteogênica, particularmente liga à biomateriais usados em engenharia de tecidos. Este projeto objetiva o desenvolvimento de uma metodologia de análise empregando-se a FT-Raman para identificação e quantificação de componentes bioquímicos presentes em meios de cultura condicionados por MSCs, com ou sem indução à diferenciação osteogênica. Todos os experimentos foram realizados entre as passagens 3 e 5 . Para essas análises, as MSCs foram cultivadas sobre arcabouços de polímeros biorreabsorvíveis de poli (hidroxibutirato-co-hidroxivalerato) (PHBV) e o poli ( $\varepsilon$-caprolactona) (PCL). As MSCs (GIBCO ${ }^{\circledR}$ ) foram inoculadas nos polímeros puros e na mistura 75:25 de PHBV / PCL (amostras densas e porosas). As células foram mantidas em DMEM (com baixa glicose) contendo GlutaMAX® e 10\% de SFB a 37oC com 5\% de CO2 por 21 dias. A própria placa foi usada como controle. Os meios de cultura condicionados foram coletados e analisadas em FT-Raman para sondagem de grupos funcionais, bem como possíveis variações moleculares associadas com a diferenciação e metabolismo celular. Foi possível discernir grupos funcionais de moléculas específicas no meio condicionado, como colesterol, fosfatidilinositol, triglicerídeos, forma Beta de polipeptídeos, regiões de amida e ligações de hidrogênio de proteínas, além da expressão de DNA. Na presente avaliação, a FT-Raman apresentou como uma técnica de resolução limitada, uma vez que modos vibracionais de estiramento próximos ou mesmo iguais podem ser expressos por moléculas diferente, dificultando a análise. Não houve variações nas leituras entre as amostras estudadas, concluindo-se que a FT-Raman não atendeu às expectativas nas condições estudadas.
\end{abstract}

Palavras-chave: biomateriais, engenharia de tecidos, diferenciação celular, espectroscopia vibracional.

*e-mail: arnaldo.santos@ufabc.edu.br

Received: December 14, 2020 - Accepted: May 13, 2021

This is an Open Access article distributed under the terms of the Creative Commons Attribution License, which permits unrestricted use, distribution, and reproduction in any medium, provided the original work is properly cited. 


\section{Introduction}

Tissue engineering is an interdisciplinary field that applies the principles of engineering and life sciences to the development of biological substitutes that can restore, maintain or improve the function of tissue or organs. Such biological substitutes are referred to as biomaterials, components designed to interact with biological systems, facilitating the regeneration or replacement of damaged tissues (Santos Junior and Zavaglia, 2016). In addition to biomaterials, cells are also very important components in tissue engineering. One of the most widely used cells are mesenchymal stem cells (MSCs). These cells can be stimulated to differentiate into cells of the mesenchymal lineage such as adipose, cartilage and bone cells. MSCs have attracted much attention as a potential cell population for use in regenerative medicine and tissue engineering. Actions of MSCs may include direct differentiation to become different cell types, including bone and cartilage cells, attraction and recruitment of other cells, or creation of a regenerative environment via production of growth factors (Leach and Whitehead, 2018; Lin et al., 2018). For tissue engineering applications, the cells-biomaterials interaction is modulated by the material properties and scaffold characteristics (Carletti et al., 2011).

One biomaterial used in tissue engineering is poly(hydroxybutyrate-co-hydroxyvalerate) (PHBV), a natural thermoplastic produced by bacteria that exhibits good biocompatibility and resistance. This polymer is being used experimentally as implant for the repair of small bone fractures and spinal cord injuries (Rivera-Briso and Serrano-Aroca, 2018). Studies have evaluated the growth of MSCs on PHBV and reported good results in terms of cell adhesion, spreading and differentiation (Zhong et al., 2019). Another polymer widely used under experimental conditions is poly( $\varepsilon$-caprolactone) $(\mathrm{PCL})$, a polyester that is degraded by hydrolysis at physiological $\mathrm{pH}$. This polymer exhibits good tissue compatibility and is easily processed. Polymer blends can be used to complement the functions and characteristics of each polymer in order to optimize their use in tissue engineering. For example, the properties of PHBV and PCL can complement each other (Casarin et al., 2011). Here, we used dense and porous scaffolds of these polymers in pure form or as blends to investigate the activity with MSC-conditioned culture medium.

One of the difficulties encountered in tissue engineering is assessing the metabolism of cells cultured on materials. Few studies have addressed the metabolism of cells in culture, notably identification of the components present in cell-conditioned culture medium. Our study aimed to evaluate the conditioned culture medium by FT-Raman spectroscopy in order to obtain information that would allow us to assess parameters of cell activity.

FT-Raman spectroscopy is a vibrational spectroscopic technique that can be used to optically probe molecular changes associated with normal and altered tissues. The method was described in 1928 by the Indian physicist Chandrasekhara Venkata Raman, who received the Nobel Prize in Physics two years later for his work (Mitsutake et al. 2019). Raman spectra express intensity as a function of the difference in energy between incident and scattered photons, which are obtained with a monochromatic laser beam that strikes a sample. The loss (or gain) in photon energies corresponds to the difference in final and initial vibrational energy levels of the molecules participating in the interaction. The resulting spectra are characterized by changes in the wavenumber (inverse of the wavelength in $\mathrm{cm}^{-1}$ ) of the incident frequency. The difference in frequency between the incident and scattered light is called Raman shift, which is unique for specific molecules. Raman vibrational modes are spectrally narrow and can be associated with the vibration of a particular chemical bond or of a single functional group in a given molecule (Mitsutake et al., 2019, Kong et al., 2015).

There are a large number of studies reporting the use of FT-Raman spectroscopy to investigate biological tissues such as bones, cornea, cervical tissues, epithelial tissue, lung, breast, skin, gastrointestinal tissue, brain, oral tissue, and liver, as well as heme proteins, atherosclerotic plaques, serum, human coronary arteries, lymphocytes, human erythrocytes, and cancer cells (reviewed in Movasaghi et al., 2007). The objective of FT-Raman spectroscopy is generally to identify spectral differences between normal and pathological biological tissues, in addition to the quantification of biochemical and metabolic components present in biological fluid samples (Mitsutake et al., 2019, Raniero et al., 2011; Andrade Bitar et al., 2012). Besides the above descriptions, we found no study reporting the use of FT-Raman spectroscopy for assessing cell-conditioned culture medium in vitro.

The aim of the present study was to evaluate the use of FT-Raman spectroscopy for the identification of biochemical and metabolic components present in conditioned culture media derived from MSCs with or without induction of osteogenic differentiation. In addition, the study aimed to identify molecules expressed in MSC-conditioned culture media that could indicate variations in the behavior of cells cultured on dense and porous PHBV and PCL polymers used in pure form or as blends, as well as molecules or functional groups associated with cell metabolism or differentiation.

\section{Materials and Methods}

\subsection{Preparation of the poly(hydroxybutyrate-co- hydroxyvalerate) and poly(caprolactone) polymers}

The materials was made as previously reported (Casarin et al., 2011). Polymers consisting of PHVB (12\% wt, Aldrich) with $12 \%$ valerate and PCL (Aldrich, Mn 7000090000 ) with a reported molecular mass of $50,000 \mathrm{~g} / \mathrm{mol}$ were used. The materials were dissolved in $5 \%$ chloroform (w/w) (Vetec Química) and transferred to a Petri dish for solvent evaporation. For the creation of pores in the porous membranes, sieved sodium chloride as porogenic agent was added to the chloroform solution. The solutions were poured into Petri dishes and left under a fume hood for evaporation of the solvent. After complete evaporation, the dense membranes were stored in a desiccator under vacuum. The porous membranes were immersed in distilled water for $24 \mathrm{~h}$ to wash out the salt and transferred to $95 \%$ 
alcohol for dehydration. The samples were again placed under a fume hood for evaporation and finally stored in a desiccator. Pure polymers and PHBV/PCL blends (75/25) were produced. The tests adopted in this study are in accordance with current international standards (ISO, 2009). The polymers were disinfected with $70 \%$ alcohol for $16 \mathrm{~h}$ prior to cell culture.

\subsection{Cell culture}

Rat MSC (GIBCO® Rat (SD) Mesenchymal Stem Cells), from the bone marrow of Sprague Dawley rats, was used. This cell line was purchased from Invitrogen (Brazil). The cells were maintained at $37^{\circ} \mathrm{C}$ in a $5 \% \mathrm{CO}_{2}$ atmosphere in DMEM medium (with low glucose) containing GlutaMAX®-I and 10\% fetal bovine serum (FBS, Gibco). The medium was always changed in the case of acidification and subcultures were prepared two or three times a week, always under conditions of semi-confluence, according to manufacturer recommendation. All experiments were carried out between passages 3 and 5 .

\subsection{Induction of osteogenic differentiation in mesenchymal stem cells}

Mesenchymal stem cells were inoculated at a concentration of $2 \times 10^{5}$ cells/well onto the pure polymers and PHBV/PCL blends (dense and porous samples). The plate itself was used as control. The cells were maintained in DMEM (with low glucose) containing GlutaMAX® and $10 \% \mathrm{FBS}$ at $37^{\circ} \mathrm{C}$ with $5 \% \mathrm{CO}_{2}$. Then, the medium of the plates was replaced with medium specific for osteogenic differentiation (StemPro Osteocyte Differentiation, Gibco). One culture containing only DMEM (low glucose) with GlutaMAX® and 10\% FBS was used as control, with regular changes of the medium. The media were changed every 3 days over a period of 21 days according to the specifications of the manufacturer of MSCs and media. The medium of the plates (including controls) was then transferred to Eppendorf ${ }^{\circledR}$ centrifuge tubes and frozen after 7, 14 and 21 days in differentiation medium.

Morphological features and the establishment of confluence were monitored under a microscope throughout the cell culture period. The medium was stained with alizarine red to demonstrate differentiation into bone cells.

\subsection{Analysis of culture medium by FT-Raman spectroscopy}

For identification of the vibrational spectral bands and probing of functional groups and/or molecular alterations associated with differentiation and metabolism, the 21 days medium conditioned by cells grown in plates or on pure or blend PHBV and PCL polymers were analyzed in an FT-Raman instrument (Varian ${ }^{\circledR}$ ) using first the 96-well plate module and then the quartz cuvette module. Both analyses aimed to identify functional groups and specific molecules secreted into the medium. For FTIR analysis in the measurement range of 4000 to $550 \mathrm{~cm}$. The spectra were collected in the transmittance mode, with a resolution of $4 \mathrm{~cm}-1$ in 100 scans per measurement. The analyses in triplicates were carried out at the Multiuser experimental center (CEM), Federal University of ABC, Santo Andre.

\section{Results}

\subsection{Culture conditions and differentiation of mesenchymal} stem cells

The Figure 1 shown de scaffold structure of pure and blend PHBV and PCL, in dense our porous forms.

The MSCs were kept at $100 \%$ confluence to evaluate the first signs of differentiation even in the absence of addition of any factor to the medium. The morphology observed was compatible with that described in the literature. There were elongated cells, with retraction of cellular projections at higher density. Figure 2 shows the induction of osteogenic differentiation in culture plate in semiconfluent and confluent cells and cells stained with alizarine red to demonstrate the deposition of calcium. The cells were also capable to differentiate on PHBV and PCL scaffolds (dada do not shown).

\subsection{FT-Raman spectroscopy}

To assess the potential of FT-Raman spectroscopy for the analysis of components present in cell-conditioned media, conditioned culture media collected under the following experimental conditions were used: 1) MSCs cultured on plates; 2 ) MSCs cultures on dense and porous PHBV; 3) MSCs cultured on dense and porous PHBV/PCL blends (75:25); 4) MSCs cultured on dense and porous PCL. In all cases, the cells exhibited the typical pattern observed after the induction of osteogenic differentiation. Cell-free medium was used as control. We use only the 21 days cell-conditioned media, with the longest time of cell differentiation.

The research question of this study refers to the possibility of identifying specific molecules in conditioned culture medium. Under these conditions, molecules would be much more diluted than in previous experimental studies that almost always used tissue samples obtained during biopsy or autopsy.

First, the FT-Raman scanning module for 96-well plates was used, which permits rapid, simultaneous and comparative analysis of liquid samples. The results obtained with this module did not provide sufficient resolution to analyze metabolic differences under the different experimental conditions. The same results were obtained for samples grown on the polymeric materials, in which the spectral curves overlapped (data not shown). Thus, under the conditions of the present study, this analysis method does not provide sufficient resolution to meet our objectives.

We therefore used another module of the Raman spectrometer, the quartz cuvette. This analysis is performed individually (per sample), rendering it much slower but potentially more accurate. This module improved the resolution of the analyses. Differences compared to the spectra obtained with the other module were observed, which could be investigated in future studies. Table 1 and Figure 3 show the results of analysis of the conditioned culture media derived from cells grown on the dense and porous polymers, in which the reading obtained for cellfree media was subtracted as baseline. According to the review of Movasaghi et al. (2007), the stretching modes 

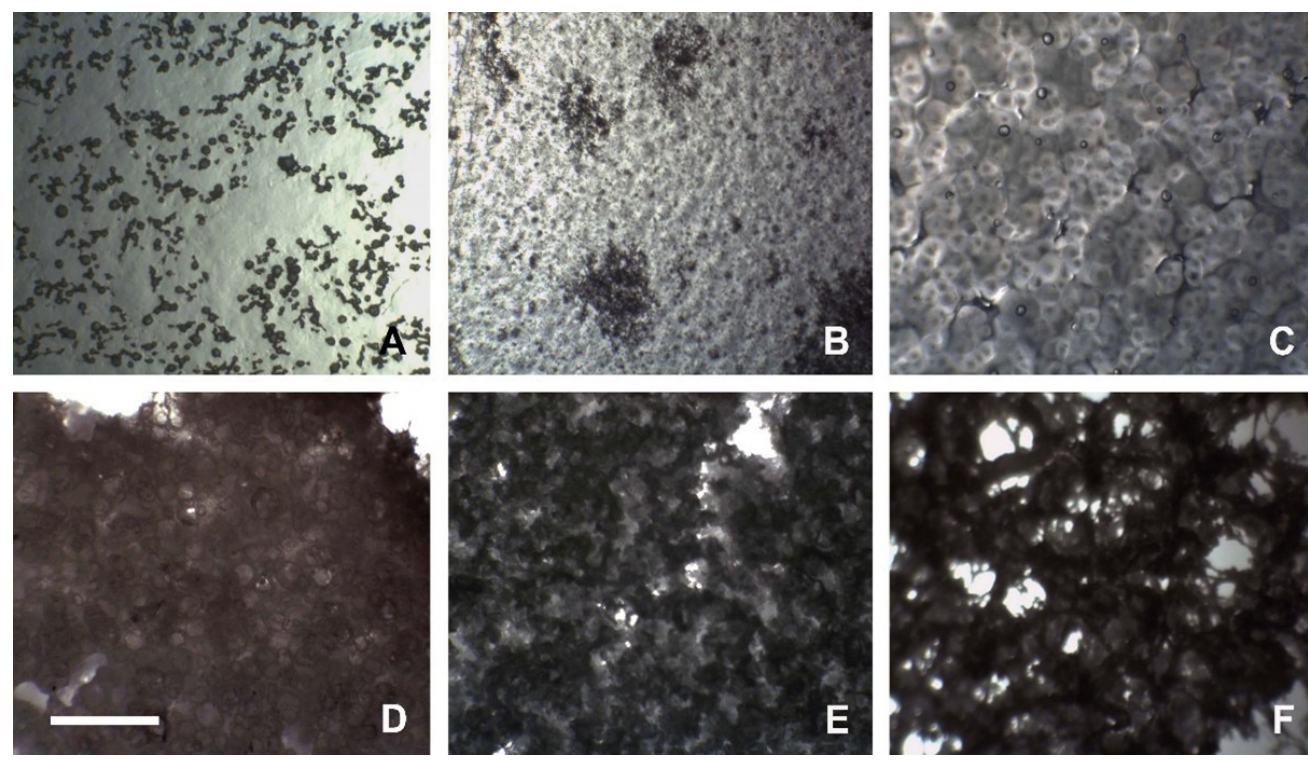

Figure 1. Scaffold structure: (A) dense PHBV; (B) dense 75:25; (C) dense PCL; (D) porous PHBV; (E) porous 75:25, (F) porous PCL. Scale bar: $100 \mu \mathrm{m}$ for all pictures.
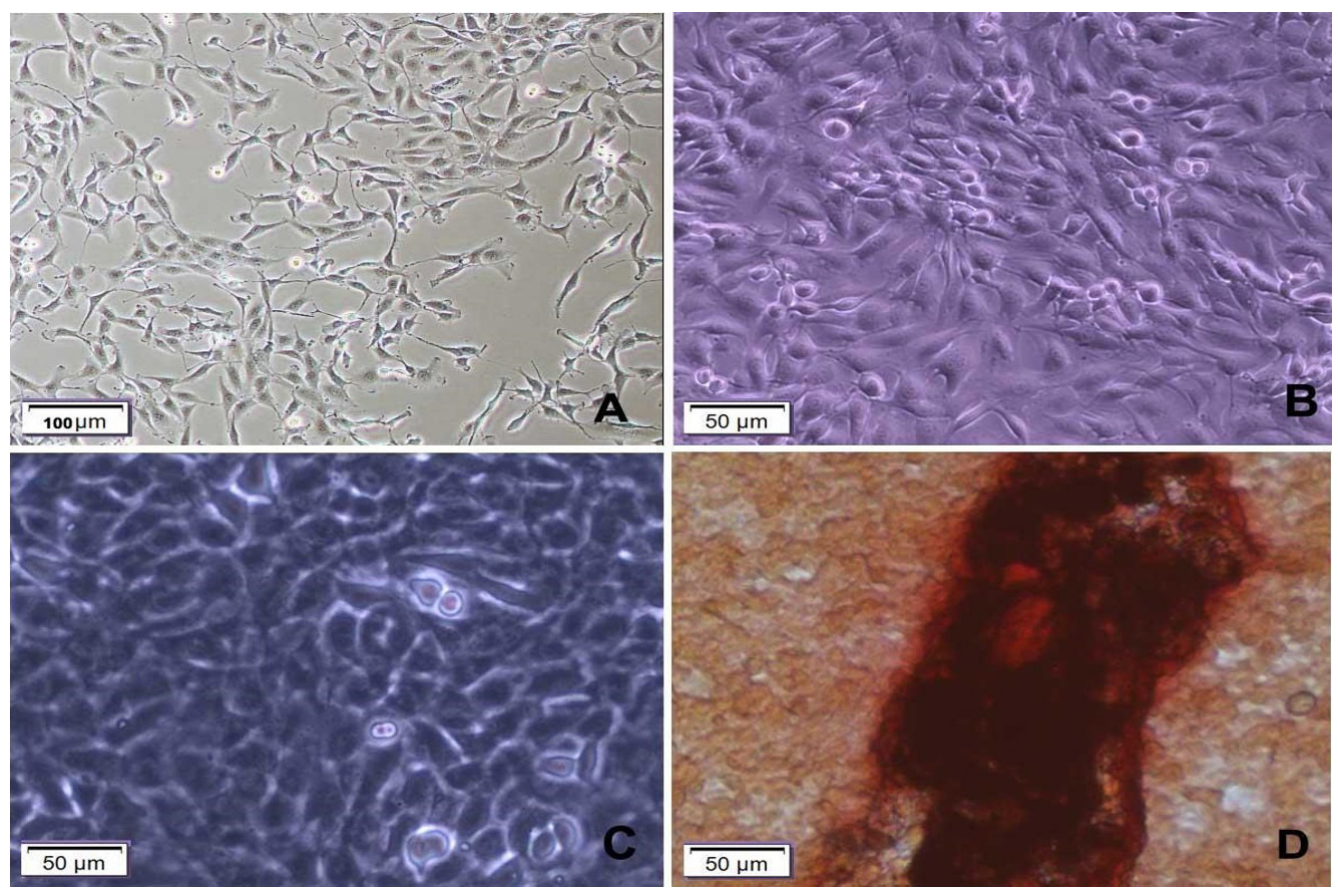

Figure 2. Induction of osteogenic differentiation in MSCs cultured on culture plate to semiconfluence (A) and confluence (B), at the beginning of cell cluster formation (C) and stained with alizarin red (demonstration of calcium) after 2 weeks of culture and differentiation (D). The red color in $\mathrm{D}$ indicates the region with calcium deposition. Scale bar: $50 \mu \mathrm{m}$.

of biological interest start at $415 \mathrm{~cm}^{-1}$. Thus, the spectra shown in the graphs start at $410 \mathrm{~cm}^{-1}$.

\section{Discussion}

Mesenchymal stem cells are an attractive research object and their patterns of adhesion, growth and differentiation have been extensively studied (Leach and Whitehead, 2018; Lin et al., 2018). However, basic studies on the metabolism of these cells are scarce, particularly studies of cells grown on biomaterials. This was one of the objectives of the use of FT-Raman spectroscopy. Classical data indicate that the growth substrates have an impact on the early stages of cell adhesion and spreading and consequently cause 
Table 1. Wavenumbers identified in the FT-Raman spectrum and their interpretation.

\begin{tabular}{cc}
\hline Vibrational mode & Characteristic of \\
\hline $416 \mathrm{~cm}^{-1}$ & Cholesterol \\
$435 \mathrm{~cm}^{-1}$ & Cholesterol \\
$788 \mathrm{~cm}^{-1}$ and & $\mathrm{C}_{5}^{\prime}-\mathrm{O}-\mathrm{P}-\mathrm{O}-\mathrm{C}_{3}^{\prime}$ phosphodiester bands in DNA; DNA \\
$800 \mathrm{~cm}^{-1}$ & Typical geometric structures of phosphate ion interactions \\
$1002 \mathrm{~cm}^{-1}$ & C-C stretch for aromatic rings; phenylalanine (collagen assignment) \\
$1070 \mathrm{~cm}^{-1}$ & Triglycerides (fatty acids) \\
$1626 \mathrm{~cm}^{-1}$ & Symmetric PO ${ }_{2}^{-}$stretch in DNA (represents DNA in the cell) \\
$1640 \mathrm{~cm}^{-1}$ & C=C stretching \\
$1650 \mathrm{~cm}^{-1}$ & Amide C=O stretch of $\beta$-subunit polypeptides \\
& Amide I band (protein band) \\
$3200 \mathrm{~cm}^{-1}$ & C=C stretch of amide I \\
$3229 \mathrm{~cm}^{-1}$ & Amide I absorption band of proteins \\
& O-H and N-H stretch vibrations \\
& $\mathrm{N}-\mathrm{H}$ stretch vibration of proteins \\
\hline
\end{tabular}

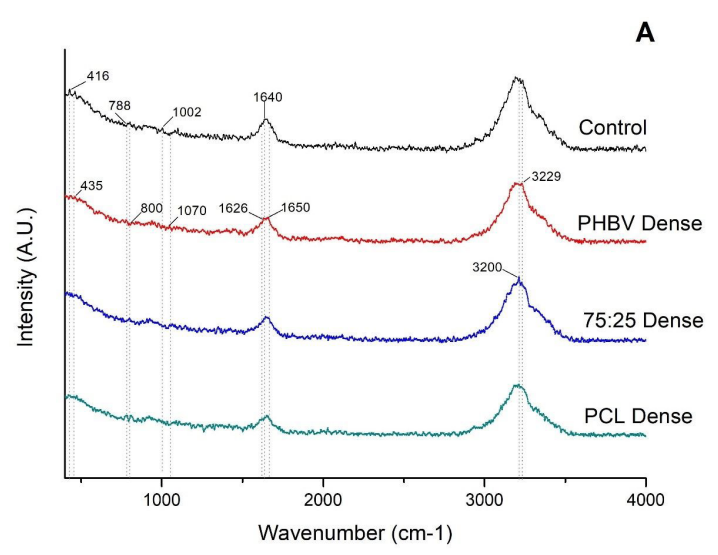

B

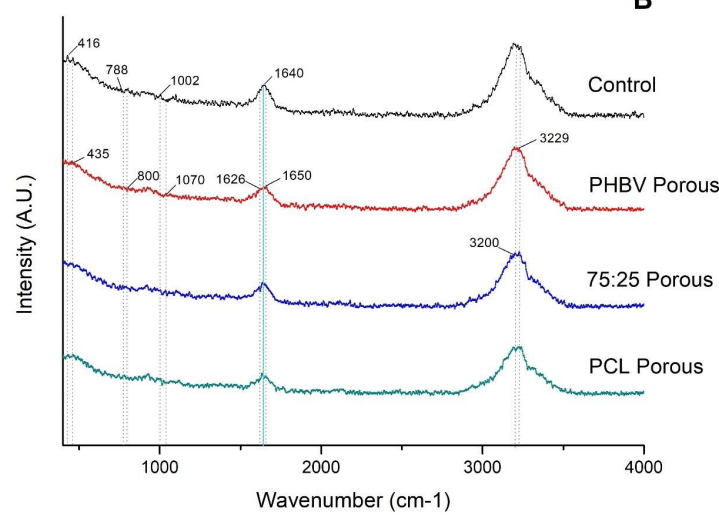

Figure 3. FT-Raman spectroscopy (individual module) analysis of culture media from cells grown on dense and porous polymers. (A) Conditioned medium derived from cells grown on dense polymers; (B) Conditioned medium derived from cells grown on porous polymers. changes in cell morphology. On the other hand, osteogenic differentiation is inhibited in the presence of hypoxia, while chondrogenesis occurs under both hypoxic and hyperoxic conditions, with the chondrogenic phenotype being more stable in hypoxia (Yuan et al., 2019). These phenomena might be associated with the energy metabolism of the underlying cells, which establishes a relationship between glycolysis and oxidative phosphorylation. Knowledge about the energy metabolism of MSCs contributes to provide adequate growth conditions for these cells, increasing the cell yield for use in regenerative medicine or even tissue engineering (Pattappa et al., 2011).

Studies evaluating changes in the metabolism of MSCs during differentiation, particularly osteogenic or chondrogenic differentiation are scarce. Furthermore, when addressing this topic, the studies usually focus on the uptake of glucose and oxygen (Yuan et al., 2019; Pattappa et al., 2011). On the other hand, studies on the metabolism of MSCs, or other cell types, in tissue engineering scaffolds are a gap in the scientific literature. Many studies review the structure, composition and biological response to PHBV (Goonoo et al., 2017) or PCL (Siddiqui et al., 2018), but the cell parameters evaluated is cell adhesion, proliferation and differentiation. Is very rare a discussion of cell metabolism.

Within this context, the present study aimed to identify by FT-Raman spectroscopy molecules released into conditioned culture medium that could provide insights into the activity of cells grown on biomaterials. Analysis of spectral patterns represented by different vibrational stretching modes showed the expression of lipids such as cholesterol, with wavenumbers ranging from 416 to $435 \mathrm{~cm}^{-1}$ (Krafft et al., 2005). This group was the only one expressing the mode at $1070 \mathrm{~cm}^{-1}$, corresponding to triglycerides (Movasaghi et al., 2007). 
Another vibrational mode found was $1626 \mathrm{~cm}^{-1}$, which corresponds to the Beta form of polypeptides (Shaw and Mantsch, 1999). In addition, vibrational modes in the range of 788 to $800 \mathrm{~cm}^{-1}$ occurred in all samples, corresponding to DNA and typical geometric structures of phosphate ion interactions (Notingher et al., 2004). The vibrational modes expressed in the range of 1640 to $1650 \mathrm{~cm}^{-1}$ demonstrate the presence of amide and proteins of irregular structures (Agarwal et al., 2006; Malini et al., 2006). A region with many $\mathrm{OH}-\mathrm{NH}-\mathrm{CH}$ stretch vibrations of proteins exists between 2300 and $3800 \mathrm{~cm}^{-1}$ and hydrogen bonding to oxygen and nitrogen is demonstrated by the vibrational modes expressed at $3200 \mathrm{~cm}^{-1}$ (Eckel et al., 2001) and at $3229 \mathrm{~cm}^{-1}$ we have $\mathrm{N}-\mathrm{H}$ vibrational modes of proteins (Movasaghi et al., 2007).

Previous studies demonstrated that FT-Raman spectroscopy can be used to evaluate the quantity and distribution of cholesterol (Van de Poll et al., 2001). Other authors also used this tool to predict the concentrations of different parameters in serum and ultrafiltered serum, showing the expression of cholesterol, triglycerides, glucose and lipoproteins, among other components (Rohleder et al., 2004). We found no variations in these molecules. No variations were observed between the different polymer samples studied.

One of the objectives of the present study was to determine whether FT-Raman spectroscopy could be useful for the analysis of cell-conditioned culture medium. Data in the literature indicate this possibility. The present results show the occurrence of lipids such as cholesterol, phosphatidylinositol and triglycerides; beta-subunit polypeptides; hydrogen bonding to oxygen and nitrogen; amide and proteins of irregular structures, as well as DNA expression. However, we were unable to identify more complex molecules. In our study, the resolution of the technique is limited; different molecules may have similar or even the same stretching vibrations, a fact that makes analysis difficult. In addition, molecules in culture medium are much more diluted than in studies using tissue samples or the cited biological fluids. No variations in the readings were observed between the samples studied. The FT-Raman technique did not meet the expectations under the cell culture conditions studied.

\section{Acknowledgements}

We thank Fapesp (grant 2015/24374-2) for financial support and Multiuser Experimental Center (CEM) of Propes/UFABC.

\section{References}

AGARWAL, R., TANDON, P. and GUPTA, V.D., 2006. Phonon dispersion in poly (dimethylsilane). Journal of Organometallic Chemistry, vol. 691, no. 13, pp. 2902-2908. http://dx.doi.org/10.1016/j. jorganchem.2006.02.032.

ANDRADE BITAR, R., DA SILVA MARTINHO, H., ZAMBELLI RAMALHO, L.N., DOS SANTOS JUNIOR, A.R., SILVA RAMALHO, F., RANIERO, L. and MARTIN, A.A., 2012. Study of aggressiveness prediction of mammary adenocarcinoma by Raman spectroscopy.
Proceedings SPIE BiOS, vol. 8219, pp. 821914. http://dx.doi. org/10.1117/12.909159.

CARLETTI, E., MOTTA, A. and MIGLIARESI, C., 2011. Scaffolds for tissue engineering and 3D cell culture. Methods in Molecular Biology (Clifton, N.J.), vol. 695, pp. 17-39. http://dx.doi.org/10.1007/9781-60761-984-0_2. PMid:21042963.

CASARIN, S.A., MALMONGE, S.M., KOBAYASHI, M. and AGNELLI, J.A.M., 2011. Study on in vitro degradation of bioabsorbable polymers poly(hydroxybutyrate-co-valerate) (PHBV) and poly(caprolactone) (PCL). Journal of Biomaterials and Nanobiotechnology, vol. 2, no. 3, pp. 207-215. http://dx.doi. org/10.4236/jbnb.2011.23026.

ECKEL, R., HUO, H., GUAN, H.-W., HU, X., CHE, X. and HUANG, W.-D., 2001. Characteristic infrared spectroscopic patterns in the protein bands of human breast cancer tissue. Vibrational Spectroscopy, vol. 27, no. 2, pp. 165-173. http://dx.doi.org/10.1016/ S0924-2031(01)00134-5.

GOONOO, N., BHAW-LUXIMON, A., PASSANHA, P., ESTEVES, S.R. and JHURRY, D., 2017. Third generation poly(hydroxyacid) composite scaffolds for tissue engineering. Journal of Biomedical Materials Research. Part B, Applied Biomaterials, vol. 105, no. 6, pp. 16671684. http://dx.doi.org/10.1002/jbm.b.33674. PMid:27080439.

INTERNATIONAL ORGANIZATION FOR STANDARDIZATION - ISO, 2009 [viewed 14 December 2020]. ISO 10993-5 (E), 2009. Biological evaluation of medical devices. Part 5: Tests for cytotoxicity: in vitro methods [online]. Genebra: ISO. Available from: https://www.iso.org/obp/ui\#iso:std:iso:10993:-5:ed3:v1:en

KONG, K., KENDALL, C., STONE, N. and NOTINGHER, I., 2015. Raman spectroscopy for medical diagnostics - From in-vitro biofluid assays to in-vivo cancer detection. Advanced Drug Delivery Reviews, vol. 89, pp. 121-134. http://dx.doi.org/10.1016/j. addr.2015.03.009. PMid:25809988.

KRAFFT, C., NEUDERT, L., SIMAT, T. and SALZER, R., 2005. Near infrared Raman spectra of human brain lipids. Spectrochimica Acta. Part A, Molecular and Biomolecular Spectroscopy, vol. 61, no. 7, pp. 1529-1535. http://dx.doi.org/10.1016/j.saa.2004.11.017. PMid: 15820887.

LEACH, J.K. and WHITEHEAD, J., 2018. Materials-directed differentiation of mesenchymal stem cells for tissue engineering and regeneration. ACS Biomaterials Science E Engineering, vol. 4, no. 4, pp. 1115-1127. http://dx.doi.org/10.1021/ acsbiomaterials.6b00741. PMid:30035212.

LIN, H., SOHN, J., SHEN, H., LANGHANS, M.T. and TUAN, R.S., 2018. Bone marrow mesenchymal stem cells: aging and tissue engineering applications to enhance bone healing. Biomaterials, vol. 203, pp. 96-110. http://dx.doi.org/10.1016/j. biomaterials.2018.06.026. PMid:29980291.

MALINI, R., VENKATAKRISHMA, K., KURIEN, J., PAI, K.M., RAO, L., KARTHA, V.B. and MURALI KRISHNA, C., 2006. Discrimination of normal, inflammatory, premalignant, and malignant oral tissue: A Raman spectroscopy study. Biopolymers, vol. 81, no. 3, pp. 179-193. http://dx.doi.org/10.1002/bip.20398. PMid:16231284.

MITSUTAKE, H., POPPI, R. and BREITKREITZ, M., 2019. Raman imaging spectroscopy: History, fundamentals and current scenario of the technique. Journal of the Brazilian Chemical Society, vol. 30, no. 11, pp. 2243-2258. http://dx.doi.org/10.21577/01035053.20190116 .

MOVASAGHI, Z., REHMAN, S. and REHMAN, I.U., 2007. Raman spectroscopy of biological tissues. Applied Spectroscopy Reviews, vol. 42, no. 5, pp. 493-541. http://dx.doi. org/10.1080/05704920701551530. 
NOTINGHER, I., GREEN, C., DYER, C., PERKINS, E., HOPKINS, N., LINDSAY, C. and HENCH, L.L., 2004. Discrimination between ricin and sulphur mustard toxicity in vitro using Raman spectroscopy. Journal of the Royal Society, Interface, vol. 1, no. 1, pp. 79-90. http://dx.doi.org/10.1098/rsif.2004.0008. PMid:16849154.

PATTAPPA, G., HEYWOOD, H.K., DE BRUIJN, J.D. and LEE, D.A., 2011. The metabolism of human mesenchymal stem cells during proliferation and differentiation. Journal of Cellular Physiology, vol. 226, no. 10, pp. 2562-2570. http://dx.doi.org/10.1002/ jcp.22605. PMid:21792913.

RANIERO, L., CANEVARI, R.A., RAMALHO, L.N.Z., RAMALHO, F.S., DOS SANTOS, E.A.P., BITAR, R.A., JALKANEN, K.J., MARTINHO, H.S. and MARTIN, A.A., 2011. In and ex vivo breast disease study by Raman spectroscopy. Theoretical Chemistry Accounts, vol. 130, no. 4-6, pp. 1239-1247. http://dx.doi.org/10.1007/ s00214-011-1027-4.

RIVERA-BRISO, A.L. and SERRANO-AROCA, A., 2018. Poly(3hydroxybutyrate-co-3-hydroxyvalerate): enhancement strategies for advanced applications. Polymers, vol. 10, no. 7, pp. 732. http://dx.doi.org/10.3390/polym10070732. PMid:30960657.

ROHLEDER, D., KIEFER, W. and PETRICH, W., 2004. Quantitative analysis of serum and serum ultrafiltrate by means of Raman spectroscopy. Analyst (London), vol. 129, no. 10, pp. 906-911. http://dx.doi.org/10.1039/b408927h. PMid:15457321.

SANTOS JUNIOR, A.R. and ZAVAGLIA, C.A.C. Tissue engineering concepts. In: S HASHMI, ed. Reference Module in Materials Science and Materials Engineering. Oxford: Elsevier, 2016. pp. 1-5.
SHAW, R.A. and MANTSCH, H.H., 1999. Vibrational biospectroscopy: from plants to animals to humans. A historical perspective. Journal of Molecular Structure, vol. 480-481, pp. 1-13. http:// dx.doi.org/10.1016/S0022-2860(98)00648-6.

SIDDIQUI, N., ASAWA, S., BIRRU, B., BAADHE, R. and RAO, S., 2018. PCL-based composite scaffold matrices for tissue engineering applications. Molecular Biotechnology, vol.60, no. 7, pp. 506-532. http://dx.doi.org/10.1007/s12033-018-0084-5. PMid:29761314.

VAN DE POLL, S.W., RÖMER, T.J., VOLGER, O.L., DELSING, D.J., BAKKER SCHUT, T.C., PRINCEN, H.M., HAVEKES, L.M., JUKEMA, J.W., VAN DER LAARSE, A. and PUPPELS, G.J., 2001. Raman spectroscopic evaluation of the effects of diet and lipid-lowering therapy on atherosclerotic plaque development in mice. Arteriosclerosis, Thrombosis, and Vascular Biology, vol. 21, no. 10, pp. 1630-1635. http://dx.doi.org/10.1161/hq1001.096651. PMid:11597937.

YUAN, X., LOGAN, T.M. and MA, T., 2019. Metabolism in human mesenchymal stromal cells: A missing link between hMSC biomanufacturing and therapy? Frontiers in Immunology, vol. 10, pp. 977. http://dx.doi.org/10.3389/fimmu.2019.00977. PMid:31139179.

ZHONG, L., HU, D., QU, Y., PENG, J., HUANG, K., LEI, M., WU, T., XIAO, Y., GU, Y. and QIAN, Z., 2019. Preparation of adenosineloaded electrospun nanofibers and their application in bone regeneration. Journal of Biomedical Nanotechnology, vol. 15, no. 5, pp. 857-877. http://dx.doi.org/10.1166/jbn.2019.2761. PMid:30890220. 